\title{
PENGUATAN KOMPETENSI PENGELOLA KOPERASI SYARIAH DI KOTA BIMA
}

\author{
Ismail1, Muhammad Rasyad Al Fajar'2, Al Maulud ${ }^{3}$ Umar Sagaf $^{4}$ \\ Institut Agama Islam (IAI) Muhammadiyah Bima, Indonesia1,2,3
}

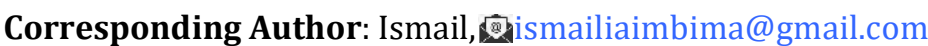

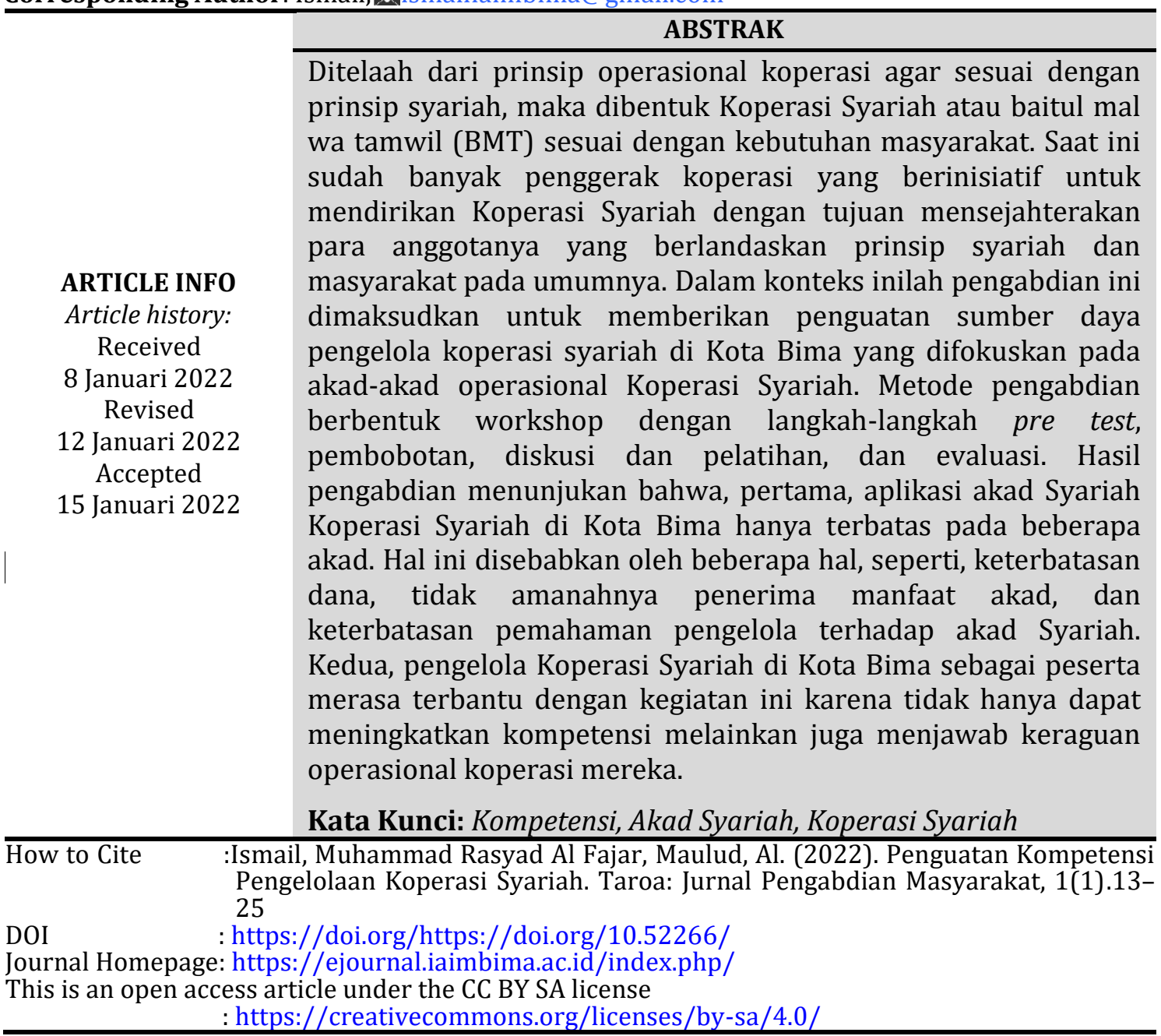

\section{PENDAHULUAN}

$\mathrm{K}$ eberadaan Koperasi diharapkan mampu mewujudkan kesejahteraan masyarakat dengan prinsip tolong menolong. Mengingat, sebagian besar masyarakat Indonesia mayoritas muslim. Ini menjadi landasan kuat bagi masyarakat akan pentingnya koperasi. Namum, dalam praktiknya, koperasi yang ada pada saat sekarang ini menggunakan sistem konvensional, yang dinilai oleh sebagian masyarakat masih terdapat riba dan ketidakjelasan akad dalam syirkah. Sedangkan dalam Islam riba adalah sesuatu yang diharamkan sebagaimana yang terdapat di dalam QS. Al Baqarah ayat 275 yang berbunyi "Allah telah menghalalkan jual beli dan mengharamkan riba". Begitu juga dengan akad dalam koperasi yang masih diragukan di masyarakat, karena dinilai belum sesuai 
dengan prinsip syariah. Untuk menjadikan prinsip operasional koperasi agar sesuai dengan prinsip syariah, maka dibentuk Koperasi Syariah atau baitul mal wa tamwil (BMT) sesuai dengan kebutuhan masyarakat. Saat ini sudah banyak penggerak koperasi yang berinisiatif untuk mendirikan Koperasi Syariah dengan tujuan mensejahterakan para anggotanya yang berlandaskan prinsip syariah dan masyarakat pada umumnya. Meski jumlahnya masih minim, namun perkembangan Koperasi Syariah sangat berkembang baik di Indonesia. Menurut Deputi Pembiayaan Kementrian Koperasi dan UKM, Braman Setyo, perkembangan kinerja Koperasi Syariah sangat baik dan berkualitas baik di sisi kesehatan koperasi, sumber daya manusia, dan teknologi informasi. Koperasi Syariah didirikan untuk meningkatkan kesejahteraan bersama antara anggota koperasi pada khususnya dan masyarakat pada umumnya, serta turut membangun tatanan perekonomian yang berbasis kerakyatan dan berkeadilan serta sesuai dengan prinsip-prinsip Islam. Pangsa pasar Koperasi Syariah yang terus meningkat didorong untuk melakukan pemberdayaan kalangan masyarakat menengah ke bawah yang diwujudkan melalui pemberian pembiayaan usaha kecil, mikro, dan menengah.

Walaupun perkembangannya dinilai positif dari sisi kuantitas untuk skala nasional, namun tidak jarang masayarakat mengkritisi kualitas kesyariahannya. Perlu diketahui, lembaga keuangan Syariah, seperti Koperasi Syariah dan Baitul al-mal, merupakan lembaga yang berkontribusi terhadap perekonomian melalui akad-akad syariahnya seperti mudharabah, musyarakah, dan lain sebagainya. Akad-akad ini diyakini sebagai alternatif dan tanpa diskriminasi terhadap para nasabahnya karena berlandaskan bagi hasil (tanpa riba). Namun, cukup disayangkan realisasi operasional para pengelola Koperasi Syariah di nilai tidak berdasarkan prinsip-prinsip Syariah yang dibuktikan dari berbagai penelitian. Secara langsung melahirkan stigma negative terhadap lembaga tersebut dan berdampak pada tidak adanya minat masyarakat. Alhasil, Koperasi Syariah tidak mengalami perkembangan kualitas, bahkan akan gulung tikar. Selain itu, minimnya pemahaman pengelola terhadap transaksi Syariah menjadi penyebab utama lahirnya stigma negative tersebut. Di sisi lain, minat masyarakat terhadap Lembaga Syariah sangatlah tinggi. Karena, sebagai masyarakat yang taat agama keberadaannya mampu menjamin kesejahteraan masyarakat di dunia dan akhirat.

Keberadaan Koperasi Syariah di kota Bima pun tidak begitu signifikan. Berdasarkan wawancara dengan pegawai KOPERINDAG Kota Bima bahwa keberadaan Koperasi Syariah berjumlah 18 unit. Belum diketahui kesehatan operasionalnya masing-masing. Tentu ini tidak sebanding dengan menjamurnya koperasi konvensional. Ini menandakan adanya masalah serius dalam pengelolaan Koperasi Syariah di kota Bima di tengah masyarakatnya yang agamis dan berkarakter Islam.

\section{TINJAU TEORITIS}

\section{Konsep Umum Koperasi}

Merujuk penjelasan undang-Undang No.17 tahun 2012 tentang perkoperasian, koperasi merupakan badan hukum yang didirikan oleh orang perseorangan atau badan hukum koperasi dengan pemisahan kekayaan para anggotanya sebagai modal untuk menjalankan usaha, yang memenuhi aspirasi dan kebutuhan bersama di bidang ekonomi, sosial dan budaya sesuai dengan nilai prinsip koperasi. Adapun menurut 
R.S.Soeriaatamdja, koperasi adalah suatu perkumpulan dari orang-orang yang atas dasar persamaan derajat sebagai manusia, dengan tidak memandang haluan agama dan politik secara sukarela masuk, untuk sekedar memenuhi kebutuhan bersama yang bersifat kebendaan atas tanggungan bersama. Asas-asas yang menjadi landasan bagi operasional koperasi di Indonesia terdiri dari: (1) Saling tolong menolong, (2) Tanggung jawab, (3) Keadilan, (4) Ekonomis, (5) Demokratis, (6) Kemerdekaan, dan (7) Pendidikan. Sebagian ulama menganggap koperasi termasuk ke dalam jenis syirkah mudharabah, tetapi menurut Muhammad Syaltut koperasi merupakan syirkah baru dan belum dikenal oleh kebanyakan umat muslim yang tidak mengandung unsur mudharabah yang biasa terdapat dalam fiqh muamalah, namun intinya dalam koperasi terdapat pembagian untung dan kerugian. Abdurrahaman Isa berpendapat bahwa koperasi termasuk ke dalam syirkah amwal atau lebih tepatnya disebut syirkah musahamah, yaitu syirkah yang dibentuk melalui pembelian saham-saham oleh para anggotanya.

Karena pelaksanaan koperasi mirip dengan bentuk kerja sama dalam Islam, maka hukum pelaksanaan koperasi secara umum diperbolehkan (mubah) selama tidak ada halhal yang mengharamkan (riba, penipuan, judi, dan sebagainya). Namun, Khalid Abdurahman Ahmad mengharamkan adanya koperasi dengan alasan prinsip-prinsip keorganisasian dan pembagian keuntungan yang menyimpang dengan syariat Islam. Begitu pula dengan An-Nabhani, koperasi merupakan organisasi yang batil dan bertentangan dengan hukum Islam. Beliau mengharamkan koperasi dengan alasannya 1) koperasi merupakan perseroan yang didirikan berdasarkan modal saja dan di dalamnya tidak terdapat satu badan persero (anggota koperasi). 2) Pembagian laba bukan menurut modal atau kerja, melainkan berdasarkan pada jasa anggotanya berupa pembelian atau produksi. Walaupun An-Nabhani dan Khalid Abdurrahman Ahmad mengharamkan adanya koperasi, namun sebagian besar ulama mendukung penetapan hukum mubah pada koperasi karena koperasi menunjukkan keselarasan dan kebaikannya dalam pandangan Islam (Pratami \& Program, 2017).

\section{Pengertian Koperasi Syariah}

Di dalam bukunya (Sukmayadi, 2020) diberikan beberapa penjelasan tentang Koperasi Syariah oleh beberapa ahli. Menurut Ahmad Ifham, Koperasi Syariah adalah usaha yang dilakukan oleh Koperasi mencakup semua kegiatan usahanya yang baik, halal, bermanfaat, dan menguntungkan berdasarkan prinsip bagi hasil bukan bunga. Sedangkan menurut Soemitra, Koperasi Syariah adalah lembaga keuangan mikro yang operasionalnya berdasarkan system bagi hasil, yang bertujuan untuk mengembangkan usaha mikro dan kecil para anggotanya agar mampu meningkatkan derajat dan martabatnya serta membela kaum tidak mampu (fakir miskin). Dari kedua pendapat di atas dapat disimpulkan bahwa koperasi Syariah merupakan suatu usaha dalam bentuk Lembaga keuangan mikro yang melandasi operasionalnya berdasarkan prinsip bagi hasil untuk meningkatkan kesejahteraan anggota sebagai prioritas utamanya.

Menurut Siregar, (2015) posisi koperasi Syariah mempunyai fungsi dan peran dalam menjalankan roda kegiatannya untuk kepentingan anggotanya. Koperasi Syariah berfungsi dan berperan antara lain: 
1) Membangun dan mengembangan potensi dan kemampuan anggotanya, dan masyarakat pada umumnya. Kopersi ini dapat berperan meningkatkan kesejahteraan sosial dan ekonomi anggota secara khusus dan masyarakat pada umumnya.

2) Memperkuat kualitas sumber daya insani anggotannya, agar menjadi lebih amanah, propesional, konsisten, konsekuen di dalam menerapkan prinsip-prinsip ekonomi Islam.

3) Membangun dan mengembangkan potensi dan kemampuan anggota pada khususnya, dan masyarakat pada umumnya, guna meningkatkan kesejahteraan sosial ekonominya.

4) Memperkuat kualitas sumber daya insani anggota, agar menjadi lebih amanah, professional (fathonah), konsisten, dan konsekuen (istiqomah) di dalam menerapkan prinsip- prinsip ekonomi islam dan prinsip-prinsip syariah Islam.

5) Berusaha untuk mewujudkan dan mengembangkan perekonomian nasional yang merupakan usaha bersama berdasarkan azas kekeluargaan dan demokrasi ekonomi.

6) Sebagai mediator antara menyandang dana dengan penggunan dana, sehingga tercapai optimalisasi pemanfaatan harta.

7) Menguatkan kelompok-kelompok anggota, sehingga mampu bekerjasama melakukan kontrol terhadap koperasi secara efektif.

8) Mengembangkan dan memperluas kesempatan kerja dan menumbuhkan-kembangkan usaha-usaha produktif anggota.

\section{Manajemen Koperasi}

Merujuk pada pasal 41 UU No.25 tahun 1992, secara umum permodalan koperasi terdiri dari modal sendiri dan modal pinjaman. Modal sendiri diperoleh dari anggota, seperti simpanan pokok dan simpanan wajib, dana cadangan, dan hibah. Sedangkan dari sisi produknya bergantung dari usaha setiap koperasi. Sifat usahanya dapat dibagi empat, misalnya koperasi produksi, konsumsi, jasa, dan simpan pinjam. Focus koperasi produksi merujuk pada usaha-usaha pengolahan, misalnya mengolah cabe hasil pertanian anggota untuk memperoleh keuntungan lebih. Untuk koperasi konsumsi, misalnya menyediakan sembako untuk para anggotanya. Sedangkan untuk koperasi usaha jasa seperti jasa angkutan, jasa kontrakan, dll. Berbeda dengan koperasi simpan pinjam. Kopearasi simpan pinjam memiliki produk dalam menarik simpanan kemudian menyalurkannya dalam bentuk pinjaman. Produk simpanan dimaksudkan untuk koperasi mencari tambahan modal selain dari modal awal, yaitu tabungan dan deposito. Untuk produk pinjaman, koperasi simpan pinjam konvensional terfokus pada pinjaman dengan pengenaan bunga. Besaran bunga bergantung pada putusan Rapat Anggota Tahunan koperasi.

Bagian terakhir dalam proses manajemen koperasi adalah Sisa Hasil Usaha (SHU). SHU merupakan laba yang berhasil dibukukan oleh koperasi selam periode tertentu setelah dikeluarkan beberapa kewajiban koperasi seperti pajak dan zakat. Biasanya SHU yang diperoleh akan diperuntukan pada bagian; cadangan, simpanan modal, simpanan pinjaman, dana social, dana pembinaan lingkungan kerja, bonus pengurus dan pengelola. Dalam operasional koperasi Syariah, manajemennya tidak berbeda dengan koperasi konvensional. Hanya saja opearasionalnya di awasi oleh Dewan Pengawas Syariah. Dewan Pengawas Syariah bertugas untuk mengawasi operasional koperasi terutama mengenai kesyariahan produknya. Sehingga produk yang dikembangkan melalui koperasi jasa 
keuangan Syariah menekankan beberapa capian diantaranya; pertama, produk simpanan, yang dapat dikembangkan dalam dua akad yaitu akad wadi'ah dan mudharabah. Kedua, produk pembiayaan, dapat dikembangkan dengan akad syirkah (kerjasama), akad ba'i (jual-beli), dan akad ijarah (Nengsih, 2016).

\section{METODE PENGABDIAN}

Kegiatan pengabdian masyarakat ini berbentuk workshop. Workshop disebut juga pelatihan atau tempat untuk para ahli memaparkan ilmunya melalui penyajian materi beserta dengan prakteknya (Sawadi, 2019). Dalam pelaksanaannya, karena bersifat pelatihan maka workshop merupakan bekal yang baik untuk para peserta dalam meningkatkan pemahamannya berkaitan dengan profesi (Sawadi, 2019). Kegiatan workshop yang kami inginkan di sini adalah berjalannya diskusi langsung dari peserta dengan narasumber berkaitan dengan tema pelaksanaan pengabdian. Kegiatan ini diselenggarakan dalam bentuk workshop Penguatan Kompetensi Pengelola Koperasi Syariah Di Kota Bima. Sasaran utama kegiatan ini yakni pengelola Koperasi Syariah. Kegiatan ini dilaksanakan di Ruang Dosen Institut Agama Islam (IAI) Muhammadiyah Bima. Metode pendekatan yang dilakukan dalam kegiatan pengabdian ini berbentuk workshop. Tahapan-tahapan yang dilalui meliputi: 1) Tahap Persiapan. Tahap persiapan meliputi penyusunan program kerja Workshop, Penyusunan modul Workshop, administrasi, pemateri, serta koordinasi lapangan.

2) Tahap Pelaksanaan. Pelaksanaan inti kegiatan secara umum mencakup dua sesi. Sesi pertama, peserta diberikan materi yang berkaitan dengan maksud kegiatan. Pembobotan ini dimaksudkan agar peserta memiliki dasar teoritis pelaksanaan akad Syariah di ruang lingkup koperasi. Sesi kedua, diskusi dan pelatihan. Diskusi dimaksudkan untuk mendapatkan feedback terhadap materi, serta analisis keterkaitannya dengan pelaksanaan mereka selama ini serta mempraktekannya. 3) Tahap Penyusunan Laporan. Seluruh rangkaian kegiatan disusun dalam bentuk pelaporan. 4) Tahap Evaluasi dan pelaporan. Tahapan ini mencakup pertanggungjawaban akhir dari proses pengabdian ini. Evaluasi dalam bentuk seminar, setelahnya disusun pelaporan akhir.

\section{HASIL DAN PEMBAHASAN}

\section{Monitoring Koperasi Syariah Kota Bima}

Langkah awal sebelum dilaksanakannya Workshop oleh dosen PKM IAI Muhammadiyah Bima adalah dengan melakukan kunjungan ke kantor Dinas Koperasi, Perindustrian, Perdagangan, Pasar dan Pertambangan (KOPERINDAG) Kota Bima. Kunjungan dimaksudkan untuk memastikan kembali keberadaan Koperasi Syariah di Kota Bima yang sebelumnya di informasikan. Hal yang kami khawatirkan adalah keberadaan Koperasi Syariah yang tidak sesuai realita (Namanya saja, tidak ada pengelola). Tentu ini akan mempersulit kami dalam menjalankan kegiatan. Sehingga, dalam kunjungan tersebut pihak KOPERINDAG menjawab kekhawatiran kami dengan menunjukan beberapa data tetntang keberadaan koperasi Syariah di Kota Bima.

Berdasarkan data yang diberikan terdapat 18 Unit Koperasi Syariah yang masih aktif di Kota Bima. Pihak KOPERINDAG juga meyakinkan bahwa 18 Unit Koperasi Syariah tersebut memiliki pengelola yang siap menghadiri kegiatan ketika di undang. Selain 
kepastian keberadaan Koperasi Syariah kami juga secara langsung memastikan kesediaan dari dinas KOPERINDAG Kota Bima untuk menjadi narasumber dalam kegitan ini. Setelah memperoleh kepastian ini kami selaku dosen $\mathrm{PkM}$ bergegas mempersiapkan kelengkapan penunjang kegiatan workshop.

Tabel 1. Daftar Koperasi Syariah Kota Bima Tahun 2021

\begin{tabular}{|c|c|c|c|}
\hline NO & NAMA KOPERASI SYARIAH & BADAN HUKUM & ALAMAT \\
\hline 1. & KPN KASABUA ADE & $\begin{array}{l}\text { 518/01/BH/Diskoperinda } \\
\text { g/XII/2002 }\end{array}$ & $\begin{array}{lccc}\text { Jl. } & \text { Soekarno Hatta } & \text { Kel. } \\
\text { Rabangodu Utara } & & \\
\end{array}$ \\
\hline 2. & KJKS SALIMAH & 200/Tahun 2012 & $\begin{array}{l}\text { Jln Iman Mbojol,Salama Kelc. } \\
\text { Nae Kec. Rasanae Barat }\end{array}$ \\
\hline 3. & KJKS KAKANDO ASRI & $\begin{array}{l}518 / 509 / \mathrm{BH} / \mathrm{PAD} / \mathrm{KWK} / . \\
23 \mathrm{XII} / 2014\end{array}$ & $\begin{array}{l}\text { Kel.Penaraga Kec.Raba Kota } \\
\text { Bima }\end{array}$ \\
\hline 4. & $\begin{array}{l}\text { KJKS HADIMUL UMMAH MUI } \\
\text { KOTA BIMA }\end{array}$ & $\begin{array}{l}\text { 007937/BH/M.KUKM.2/II } \\
\text { I/2018 }\end{array}$ & $\begin{array}{l}\text { Jln Kartini Kompleks Masjid } \\
\text { Agung Kel. Pane Kec. Ras. } \\
\text { Barat }\end{array}$ \\
\hline 5. & KSPPS SAKAKA ANGI MENA & $\begin{array}{l}006747 / \text { BH/M.KUKM.2/I/ } \\
2018\end{array}$ & $\begin{array}{l}\text { Jl. Gajahmada } \text { Gg. SMA } \\
\text { Pemuda } \\
\text { Mpunda }\end{array}$ \\
\hline 6. & $\begin{array}{lll}\text { KSPPS } & \text { NAUVAL } & \text { BERKAH } \\
\text { SYARIAH } & & \\
\end{array}$ & $\begin{array}{l}\text { 005326/BH/M.KUKM.2/IX } \\
\text { /2017 }\end{array}$ & Kel. Panggi Kec. Mpunda \\
\hline 7. & KSPPS MA'HAD ULUL ALBAAB & $\begin{array}{l}\text { 007188/BH/M.KUMKM.2/ } \\
\text { I/2018 }\end{array}$ & $\begin{array}{l}\text { Jl. Multazzam Kel. Rabangodu } \\
\text { Selatan Kec. Raba }\end{array}$ \\
\hline 8. & $\begin{array}{l}\text { KOP. SYARIAH SABUA ADE } \\
\text { MATAHO }\end{array}$ & $\begin{array}{l}011694 / \text { BH/M.KUKM.2/I/ } \\
2019\end{array}$ & $\begin{array}{l}\text { Jl. Garuda Kel. Lewirato Kec. } \\
\text { Mpunda }\end{array}$ \\
\hline 9. & $\begin{array}{l}\text { KOP. SYARIAH BAROKAH MTSN } \\
1 \text { KOTA BIMA }\end{array}$ & $\begin{array}{l}\text { 013043/BH/M.KUKM.2/IV } \\
\text { /2019 }\end{array}$ & $\begin{array}{l}\text { Jl. Sultan Salahuddin No. } 33 \\
\text { Kel. Dara Kec. Rasanae Barat }\end{array}$ \\
\hline 10. & $\begin{array}{l}\text { KOPERASI SYARIAH ANONA } \\
\text { MORICATA SPP }\end{array}$ & $\begin{array}{l}\text { 014175/BH/M.KUKM.2/VI } \\
\text { I/2019 }\end{array}$ & 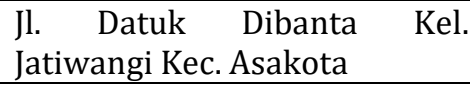 \\
\hline 11. & KSPPS NURUL IMAN WAL AMAL & $\begin{array}{l}\text { AHU-0003324.AH.01.26 } \\
\text { TAHUN } 2020\end{array}$ & $\begin{array}{l}\text { Jl. Kesejahteraan Kel. Lewirato } \\
\text { Kec. Mpunda }\end{array}$ \\
\hline 12. & $\begin{array}{lll}\text { KSPPS } & \text { PANAMA } & \text { AKBAR } \\
\text { BERSATU } & & \\
\end{array}$ & $\begin{array}{l}\text { AHU-0004917.AH.01.26 } \\
\text { TAHUN } 2020\end{array}$ & $\begin{array}{l}\text { Jl. Lintas Bedi No. } 84 \text { Kel. } \\
\text { Manggemaci Kec. Mpunda }\end{array}$ \\
\hline 13. & $\begin{array}{l}\text { KOP. SYARIAH HANDY CRAFT } \\
\text { KASAMAI }\end{array}$ & $\begin{array}{l}004185 / \mathrm{BH} / \mathrm{M}- \\
\text { KUKM.2/V/2017 }\end{array}$ & Kel. Sarae Kec. Rasanae Barat \\
\hline 14. & KPRI REKAYASA SYARIAH & 36/BH/KWK.23/VI/1995 & $\begin{array}{l}\text { Jl. Gatot Subroto No. } 22 \text { Kel. } \\
\text { Mande Kec. Mpunda (SMKN } 2 \\
\text { Kota Bima) }\end{array}$ \\
\hline 15. & $\begin{array}{ll}\text { KOPERASI } & \text { KONSUMEN } \\
\text { ALFATTAH CAHAYA RAHMAT }\end{array}$ & $\begin{array}{l}\text { AHU- } \\
0005744 . A H .01 .26 . T A H U N \\
2020\end{array}$ & Kel. Sarae Kec. Rasanae Barat \\
\hline 16. & KPRI IKHTIAR & $\begin{array}{l}\text { 796/BH/PAD/KWK.23/IV } \\
/ 1989\end{array}$ & $\begin{array}{l}\text { Jl.Seruni No.6 Saleko Kel. } \\
\text { Sarae Kec. Rasanae Barat } \\
\text { (MAN 1 Kota Bima) }\end{array}$ \\
\hline 17. & KPRI KARAWI & $\begin{array}{l}\text { 108/BH/KWR.23/VI/199 } \\
7\end{array}$ & $\begin{array}{l}\text { Jl. Garuda No. } 05 \text { Kel. Lewirato } \\
\text { Kec. Mpunda (SMKN } 3 \text { Kota } \\
\text { Bima) }\end{array}$ \\
\hline 18. & KOPWAN NILA KANTI & 23/BH/KWK.23/I/1997 & $\begin{array}{l}\text { Jl. Duku No. } 1 \text { Kel. Rabangodu } \\
\text { Utara Kec. Raba Kota Bima. }\end{array}$ \\
\hline
\end{tabular}




\section{Sistem Pengelola Koperasi Syariah Di Kota Bima}

Kegiatan Workshop dilaksanakan pada tanggal 27 Mei 2021 bertempat di ruangan dosen IAI Muhammadiyah Bima. Jumlah perwakilan koperasi yang memenuhi undangan kami sebanyak 11 unit koperasi. Kegiatan ini memberi gambaran bagaimana pelaksanaan koperasi Syariah di kota Bima dari sisi manajemen. Selanjutnya, implementasi pelaksanaan akad dapat digambarkan melalui penyampaian para peserta. Secara garis besar kami merangkumnya dalam lima bentuk akad, yaitu akad Kerjasama (syirkah), akad jual beli (Ba'i), akad sewa (Ijarah) dan akad jasa.

\section{1) Manajemen Koperasi Syariah}

Koperasi Syariah direkomendasikan bergerak di sector simpan pinjam karena dipandang memiliki transaksi yang variative dibandingkan dengan sector produksi, konsumsi, dan jasa yang sangat erat dengan akad jual beli dan ijarah. Secara operasional manajemen koperasi Syariah sama dengan koperasi konvensional, yang membedakan terletak pada dewan pengawas dan produknya yang variative. Produk-produk tersebut antara lain; produk simpanan yang dapat dikembangkan dalam akad Wadi'ah dan Mudharabah, produk pembiayaan yang dapat dikembangkan dengan akad syirkah, akad jual beli, dan ijarah. Sedangkan untuk permodalan dapat bersumber dari modal sendiri seperti simpanan pokok, simpanan wajib, dana cadangan, dan hibah.

Berdasarkan keterangan dari para pengelola koperasi Syariah Kota Bima, permodalan seperti simpanan pokok, simpanan wajib, dan dana cadangan sudah dapat dipahami karena sangat akrab dengan koperasi Syariah. Namun, terkait dengan dana hibah, mereka berharap ada perhatian khususnya dari pemerintah untuk koperasi Syariah. Implementtasi akad-akad Syariah akan sangat terbantu apabila didukung finansial yang cukup, dan tidak bisa hanya mengandalkan simpanan pokok dan simpanan wajib anggota yang jumlahnya sedikit. Masalah modal memang menjadi masalah umum Koperasi Syariah di Kota Bima untuk melanjutkan transaksi pembiayaannya. Dinas terkait perlu memperhatikan aspek permodalan jika menghendaki operasionalnya pada aspek simpan pinjam. Sebab akan sangat berbeda dengan aplikasi koperasi konvensional yang mengandalkan bunga sekian persen. Artinya, laba dari penyaluran pinjaman sudah bisa diprediksi. Sedangkan pada koperasi Syariah, tingkat likuiditas koperasi sangatlah riskan. Terutama bagi koperasi Syariah yang berbasis masyarakat. Untuk menjamin hal tersebut dibutuhkan dana yang cukup.

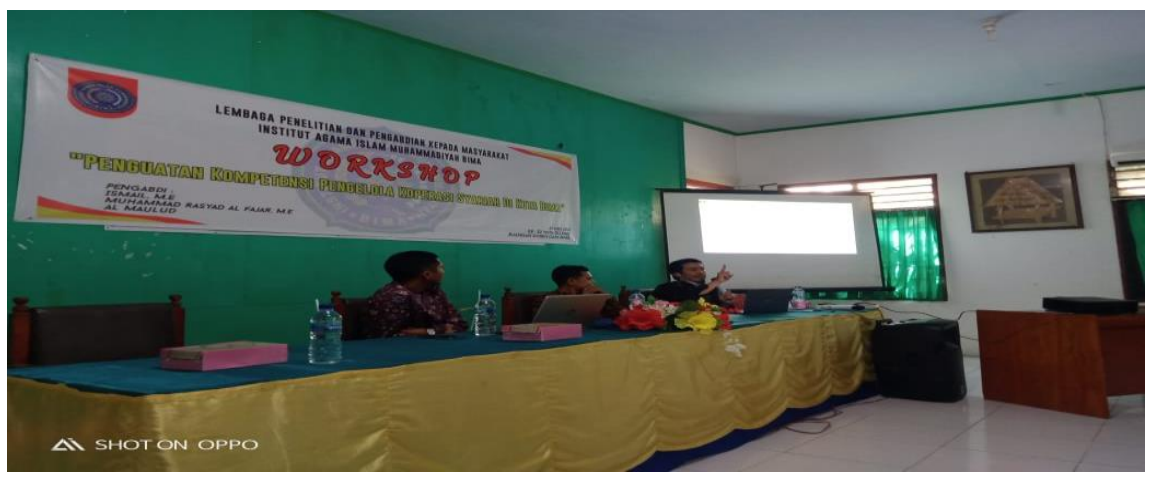

Gambar 1. Kegiatan Workshop Manajemen Koperasi Syariah 


\section{2) Pelaksanaan Akad Koperasi Syariah}

Untuk mempertajam pemahaman peserta, pemateri mengajaknya berdiskusi mengenai akad-akad Syariah yang dapat diaplikasikan Koperasi Syariah.

\section{Akad Kerjasama Musyarakah}

Musyarakah secara bahasa disebut Syirkah, yaitu percampuran harta dua orang atau lebih sehingga tidak dibedakan lagi. Akad Musyarakah merupakan akad kerjasama antara dua orang atau lebih untuk usaha tertentu kemudian masing-masing pihak berkontribusi terhadap dana, adapun keuntungan dan resikonya akan ditanggung bersama sesuai kesepakatan. Praktik Musyarakah di Koperasi Syariah Kota Bima belum terlalu banyak dipraktekan. Hanya saja akad musyarakah rutin di praktekan ketika para anggota mengumpulkan iuran simpanan pokok dalam Koperasi Syariah sebagai modal awal Koperasi. Iuran simpanan pokok ini tergolong syirkah Mufawadhah dalam akad Musyarakah. Yakni bersama-sama dalam mendirikan usaha yang keanggotaannya bisa dua atau lebih dengan berkontribusi terhadap dana dalam jumlah yang sama serta bobot kerja yang sama juga besarnya. Akad syirkah Mufawadhah sekaligus menjawab kekhawatiran dari peserta workshop tentang kehalalan simpanan pokok dalam Koperasi Syariah. Akad musyarakah yang belum banyak diketahui oleh pengelola koperasi sebenarnya memiliki peluang bagus untuk dioperasikan bersama anggota. Koperasi hanya perlu selektif dalam memilih model dan prospek usaha, misalnya dalam bentuk home industri, kantin, atau usaha UMKM lainnya.

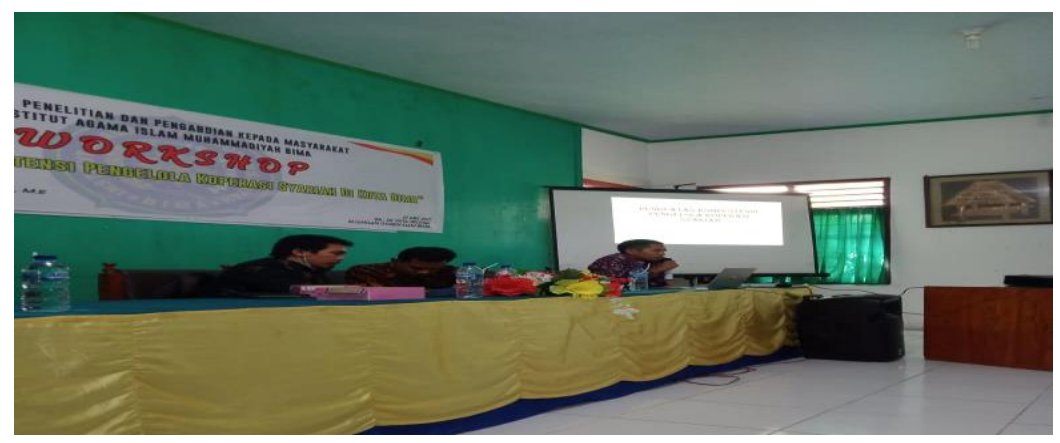

Gambar 2. Kegiatan Workshop Akad-Akad Koperasi Syariah

\section{Akad Kerjasama Mudharabah}

Akad Mudharabah adalah akad kerjasama dua orang pihak dalam suatu usaha, dimana pihak pertama sebagai penyedia modal sepenuhnya, dan pihak kedua sebagai pengelola. Setiap keuntungan dibagi bersama sesuai kesepakatan kontrak serta kerugian ditanggung pemilik modal selama bukan karena kelalaian pengelola. Akad mudharabah belum dapat diaplikasikan oleh Koperasi Syariah karena keterbatasan dana. Secara umum Koperasi Syariah kota Bima hanya mengandalkan iuran pokok dan iuran wajib yang jumlahnya tidak begitu besar. Koperasi dalam akad ini bertindak sebagai pemilik modal (Investor) yang akan dimanfaatkan sepenuhnya oleh pengelola usaha. Namun pihak koperasi enggan melakukan oleh karena beberapa alasan; dibutuhkan banyak modal dan kekhawatiran terhadap pengelola yang tidak amanah. Kalau sekiranya Koperasi Syariah 
memiliki cukup dana dapat memanfaatkan akad ini dengan beberapa kriteria akad seperti mudharabah Muthlaqah, mudaharabah muqayyadah, dan mudharabah musyarakah.

Pertama, Akad muthlaqah mempertegas terhadap pengelola dana agar berusaha sesuai dengan tujuan keberhasilan mudharabah. Apabila terjadi kerugian yang disebabkan oleh pengelola maka pengelola wajib menerima konsekunsinya, dan sebaliknya, ketika kerugian tersebut disebabkan oleh bencana atau bukan kelalaian pengelola maka di tanggung oleh pemilik modal. Kedua, mudharabah muqayyadah, yaitu akad yang dapat memberikan batasan-batasan terhadap pengelola dana (dana, cara, lokasi, atau objek investasi). Ketiga, mudharabah musyarakah, yakni pengelola dana diperkenankan mengembalikan modal secara bertahap. Apabila pengelola Koperasi Syariah yang memiliki cukup modal merasa khawatir, maka kami menyarankan untuk akad mudahrabah muqayyadah dapat dipilih karena dapat diperkuat pada kontraknya mengenai batasanbatasan dari pengelola.

\section{Akad Dalam Jual Beli (Ba'i)}

\section{(1) Murabahah}

Murabahah secara asal kata yakni ar ribhu yang bermakna kelebihan atau keuntungan. Murabahah merupakan akad jaul beli suatu barang dengan menyebutkan harga yang diperolehnya serta keuntungan yang disepakati oleh penjual dan pembeli. Atau juga dapat diartikan sebagai akad jual beli barang pada harga asal dengan tambahan keuntungan yang disepakati. Terhadap akad ini pengelola Koperasi merasa ragu terhadap praktek yang pernah dilakukan. Misal, dalam operasionalnya ia membelikan sebuah leptop untuk nasabahnya, namun kebingungan untuk menetapkan sebagai sebuah akad. Kami meyakinkan bahwa jual beli seperti itu disebut sebagai akad murabahah, dimana dapat dilakukan dengan memesannya terlebih dahulu, dibayar tunai ataupun kredit. Adapun rukun utama dalam prakteknya telah terpenuhi, yaitu adanya pelaku akad atau pembeli dan penjual yang sudah baligh, berakal, dan cakap hukum. Koperasi bertindak sebagai penjual, sedangkan anggota sebagai pembeli. Hanya saja pengelola koperasi perlu memperhatikan rukun dan syaratnya yang lain, seperti objek barang (meliputi barang dan harga), dan ijab dan qabul. Objek barang yang dijual pun tidak boleh bertentangan dengan syariah, begitu pun dengan harga jualnya. Koperasi sebagai penjual harus menunjukan kejujurannya atas harga yang ditetapkan. Apabila telah ridho, maka berlangsunglah ijab dan qobul. Barulah Operasional yang dilakukan memenuhi akad murabahah. Sebagian Koperasi Syariah di Kota Bima mengandalkan akad ini. Menurutnya, akad ini sangat cocok dengan lingkungan dan kondisi anggota yang bekerja di dunia Pendidikan.

(2) Salam

Akad jual beli salam adalah akad dengan menjual suatu barang yang penyerahannya ditunda, atau menjual barang dengan ciri-cirinya yang jelas dengan menyerahkan lebih awal uangnya, dan barangnya dikemudian hari. Sederhananya, akad salam adalah akad pesanan dengan biayanya diserahkan di muka. Pengelola koperasi hanya mengetahui akad ini dan tidak paham bagaimana operasionalnya. Akad ini bisa di praktikkan pada semua jenis barang pesanan yang barangnya tidak 
bertentangan dengan Syariah. Bisa dengan barang-barang elektronik, kendaraan, atau properti lainnya. Yang terpenting adalah spesifikasi barangnya haruslah jelas.

Akad ini cukup mudah dipraktikkan dan sangat erat dengan kebutuhan koperasi Syariah di kota Bima. Misalnya, Koperasi Syariah yang berdiri di lingkungan sekolah. Berbagai kebutuhan sekolah seperti seragam, ATK, dan lainnya, bisa dikelola oleh Koperasi melalui akad Salam. Contoh: Jual beli secara paralel yang dilakukan oleh 3 pihak, sebagai contoh pihak 1 (anggota koperasi syariah) memesan pakaian seragam sebanyak 100 setel kepada Koperasi syariah dan Koperasi Syariah memesan kembali dari Konveksi (bisa anggota koperasi atau bukan) untuk dibuatkan 100 setel seragam yang dimaksud, dan koperasi syariah membayarnya dengan uang muka dan dibayar setelah jadi, setelah selesai diserahkan ke pihak satu (anggota koperasi) dan pihak satu membayarnya baik secara tunai maupun diangsur, pembiayaan ini disebut Al Bai Istishna. Jika koperasi membayarnya dimuka disebut Bai' Salam.

\section{(3) Akad Sewa (Ijarah)}

Ijarah adalah akad pemindahan manfaat suatu barang atau jasa melalui upah sewa tanpa diikuti oleh pemindahan kepemilikan atas barang tersebut. Dengan batas waktu tertentu dan sebagai imbalannya penyewa membayar upah kepada pemilik barang yang sudah disepakati bersama. Sebagian koperasi menyediakan akad ini dalam operasionalnya dengan memanfaatkan peluang dan kondisi anggota. Misalnya, kebutuhan rumah kontrak bagi guru. Akad ijarah sebenarnya sangat sederhana, namun keterbatasan pengelola terutama asset atau jasa yang akan disewakan sangatlah terbatas. Ke depan, harapannya pihak koperasi dapat berfikir bagaimana operasional akad ijarah dapat diaplikasikan mengingat peluangnya di Kota Bima sebagai kota Pendidikan cukuplah besar. Misalnya pengadaan kos-kosan, atau jasa penyewaan lain seperti penyewaan tenda, sound system, dan lainnya.

(4) Akad Jasa

\section{- Wadi'ah}

Wadi'ah secara etimologi berasal dari kata wada'a asy-syai, bermakna meninggalkan. Alasan penamaan tersebut lantaran sesuatu yang ditinggalkan pada orang lain supaya dijaga oleh wadi' atau penerima titipan barang. Sedangkan secara Terminologi dapat merujuk pada pendapatnya Sayyid Sabiq (Antonio, 2021), Wadi'ah adalah tittipan murni dari satu pihak ke pihak yang lain, baik individu maupun badan hukum, yang harus dijaga dan dikembalikan kapan saja si penitip menghendaki. Akad Wadi'ah terbagi menjadi dua, yaitu akad Wadi'ah Yad Amanah dan Wadi'ah yad AdhDhamanah. Akad Wadi'ah Yad Amanah yaitu akad penitipan baik barang maupun uang dari anggota koperasi Syariah (Muwaddi) kepada Koperasi Syariah (Wadi'i), dan pihak Koperasi Syariah tidak boleh menggunakan titipan dari anggota tersebut dan juga tidak bertanggung jawab atas kerusakan yang tidak disebabkan oleh kelalaian pihak Koperasi Syariah. Imbalan dari transaksi ini adalah penitip wajib membayar biaya penitipannya, namun juga boleh untuk tidak membayarnya. Sedangkan akad Wadi'ah yad Adh-Dhamanah sama dengan Wadi'ah Yad Amanah. Yang membedakannya adalah prinsip Yad Amanah, yaitu pihak Koperasi Syariah boleh menggunakan barang atau uang yang dititipkan dan bertanggung jawab atas 
pengembaliannya secara utuh. Dari dua kriteria akad Wadi'ah di atas, Koperasi Syariah di Kota Bima dapat memanfaatkannya dengan baik. Penggunaan akad Wadi'ah yad Adh-Dhamanah oleh Koperasi Syariah dituntut memiliki keilmuan dan skill dalam mengelolanya mengingat titipan tersebut sewaktu-waktu dapat diambil dan menjaga likuiditas Koperasi. Selain itu, ketika koperasi memiliki sumber dana melalui wadi'ah mereka akan kesulitan mengelolanya. Ini yang menjadi kendala para pengelola Koperasi Syariah di Kota Bima dan secara umum kami menyarankan agar mengaplikasikan akad Wadi'ah Yad Amanah.

- Rahn (gadai)

Akad gadai dalam Bahasa Arab disebut sebagai rahn. Ar-rahn adalah menahan salah satu harta milik peminjam atas hata yang dipinjam. Harta yang ditahan adalah yang memiliki nilai ekonomis dan berfungsi sebagai jaminan atas harta pinjaman oleh peminjam dapat mengambil kembali seluruh atau sebagian dari piutangnya. Setelah mendapat penjelasan detil tentang akad rahn, pengelola koperasi mengira bahwa akad gadai koperasi Syariah sama seperti transaksi gadai di lembaga keuangan konvensional yang mengambil manfaat dari barang gadai. Oleh karena demikian dalam operasionalnya masih terdapat kekeliruan. seharusnya akad rahn atau gadai dalam Koperasi Syariah hanya sebagai barang jaminan atas hutang. Dan untuk memperoleh keuntungan pihak koperasi dapat mengenakan biaya titipan terhadap barang yang digadai. Biaya titipan tersebut dilakukan berdasarkan akad ijarah.

\section{Refleksi Praktik Koperasi Syariah Kota Bima}

Merujuk dari hasil workshop bahwa pengetahuan pengelola masih sangat minim. Akad-akad yang ada masih terdapat kekeliruan penafsiran sehingga melahirkan system kelola yang salah. Tidaklah heran, ketika ada penilaian masyarakat bahwa koperasi Syariah hanyalah 'label' semata. Diperlukan kehati-hatian apabila ingin mengelola potensi masyarakat muslim di kota Bima melalui pengembangan ekonomi Islam. Karena tidak hanya akan berdampak pada kehidupan dunia melainkan juga kehidupan akhirat. Kegiatan muamalah harus tetap menjunjung tinggi nilai kesyariahan, dan tetap harus dijaga operasionalnya berdasarkan dalil-dalil Islam. Ini sejalan dengan tujuan dasar pendirian koperasi Syariah yaitu membangun perekonomian berdasarkan prinsip Syariah. Artinya semua operasional yang tidak di dasari Syariah tidak diperbolehkan (Sukmayadi, 2020). Hal yang mempertegas operasional koperasi Syariah harus berdasarkan Syariah Islam termaktub pada kaidah dasar muamalah yakni "Hukum asal dalam semua bentuk muamalah adalah boleh dilakukan kecuali ada dalil yang mengharamkannya". Pentingnya operasional Syariah akan menjamin kehalalan harta, tegaknya ekonomi Islam, serta menjawab keraguan dari masyarakat yang selama ini di alami oleh Lembaga keuangan Syariah Kota Bima.

\section{SIMPULAN}

Kegiatan Pengabdian Masyarakat yang dilakukan oleh dosen IAI Muhammadiyah Bima melalui kegiatan workshop penguatan kompetensi pengelola koperasi syariah si Kota Bima telah berjalan dengan baik. Dalam pengaplikasian akad Syariah Koperasi Syariah di Kota Bima hanya terbatas pada beberapa akad. Hal ini disebabkan oleh 
beberapa hal, seperti, keterbatasan dana, tidak amanahnya penerima manfaat akad, dan keterbatasan pemahaman pengelola terhadap akad Syariah. Sisi lainnya bahwa para pengelola Koperasi Syariah di Kota Bima sebagai peserta merasa terbantu dengan kegiatan ini karena tidak hanya dapat meningkatkan kompetensi melainkan juga menjawab keraguan operasional koperasi mereka.

\section{UCAPAN TERIMA KASIH}

Penulis mengucapkan terima kasih kepada Lembaga Penelitian dan Pengabdian Kepada Masyarakat (LP2M) Institut Agama Islam (IAI) Muhammadiyah Bima yang telah memberi program hibah pengabdian masyarakat tahun 2021, sehingga pelaksanaan pengabdian terhadap keberhasilan pengabdian ini dapat diselenggarakan. Terima kasij juga disampai kepada seluruh tim pengabdian yang secara kaloboratif menyelesaikan kegitaj ini dengan tepat waktu. Pada akhirnnya kegitan pengabdian masyarakat ini juga akan berdampak pada peningkatan pemahaman serta kompetensi para pengelola koperasi Syariah di Kota Bima.

\section{DAFTAR PUSTAKA}

Antonio, S. (2021). Bank Syariah Dari Teori Ke Praktik. Gema Insani Press.

Hidayat, T. (2011). Buku Pintar Investasi Syariah. Mediakita.

Janwari, Y. (2015). Fikih Lembaga Keuangan Syariah. Pt Remaja Rosdakarya.

Nengsih, I. (2016). Manajemen Lembaga Keuangan Syariah Non Bank: Teori, Praktek, Dan Regulasi (Issue 95). Jasa Surya.

Pratami, R. M. Dan Y. Y., \& Program. (2017). Koperasi Syariah Sebagai Solusi Penerapan Akad Syirkah Yang Sah. Amwaluna: Jurnal Ekonomi Dan Keuangan Syariah, 1(2), 263275.

Rachmawati, D. W., Widalesmana, M., Toyib, M., Permatasari, N., Studi, P., Akuntansi, P., Pgri, U., \& Utara, P. I. (2019). Pelatihan Dan Workshop Pengelolaan Koperasi Di Sekolah. Caradde: Jurnal Pengabdian Kepada Masyarakat, 1(2), 162-166.

Sawadi. (2019). Improving Teacher's Social Competence Through Teacher Workshop In Sdn-I Sukajaya In 2018. Anterior Jurnal, 19(1), 79-104.

Setianingrum, A. (2016). Program Pengabdian Kepada Masyarakat Pelatihan Aplikasi Akad Jasa Keuangan Koperasi Syariah, Bagi Kelompok Umkm Di Cempaka Putih. Skie: Studi Kasus Inovasi Ekonomi, 2(2).

Siregar, R. (2015). Peranan Koperasi Dalam Meningkatkan Kesejahteraan Ekonomi Masyarakat Ditinjau Dari Hukum Ekonomi Islam. At-Tijaroh, 1(1), 220-243.

Sukmayadi. (2020). Koperasi Syariah Dari Teori Untuk Praktek. Alfabeta, 190.

Wasiaturrahma, Sulisttyowati, C., Heryati, D., \& Ajija, S. R. (2020). Improving The Cooperative Performance Through Financial Management Assistance In Koperasi 64 Surabaya. Jurnal Berdaya Mandiri, 2(1), 256-267. 